\title{
Synthesis and Pharmacology of Alkanediguanidinium Compounds that Block the Neuronal Nicotinic Acetylcholine Receptor
}

\author{
Mercedes Villarroya, ${ }^{a}$ Luis Gandía, ${ }^{a}$ Manuela G. López, Antonio G. García, ${ }^{\text {a }}$ Sénida Cueto, \\ José-Luis García-Navio ${ }^{\mathrm{b}}$ and Julio Alvarez-Builla ${ }^{\mathrm{b}, *}$ \\ "Departamento de Farmacología, Facultad de Medicina, Universidad Autónoma de Madrid, Arzobispo Morcillo, 4, 28029 \\ Madrid, Spain \\ 'Departamento de Química Orgánica, Universidad de Alcalá de Henares, E-28871 Alcalá de Henares, Madrid, Spain
}

\begin{abstract}
Taking as models the polyamine toxin fraction FTX from the funnel-web spider venom, and the guanidinium moiety of guanethidine, a series of azaalkane-1,w-diguanidinium salts were obtained. Some of them blocked ion fluxes through the neuronal nicotinic receptors for acetylcholine (nAChR). The blockade was exerted at submicromolar concentrations, suggesting a highly selective interaction with the nAChR. In fact, the active compounds on the nAChR ion channel did not recognize the voltage-dependent $\mathrm{Na}^{+}$or $\mathrm{Ca}^{2+}$ channels of bovine adrenal chromaffin cells. Therefore, these compounds may be useful tools to clarify the functions of nAChR receptors in the central and peripheral nervous systems. Copyright $(\mathbb{C} 1996$ Elsevier Science Ltd
\end{abstract}

\section{Introduction}

Mammalian nicotinic receptors for acetylcholine ( $\mathrm{nAChR}$ ) considerably differ in structure and function. Those mediating contraction at the skeletal muscle end-plate have a subunit composition $(\alpha)_{2} \quad \beta \gamma \delta$ in developing muscle and $(\alpha)_{2} \quad \beta \varepsilon \delta$ in mature muscle. Those present in neurons exhibit a much higher diversity and are constructed of combinations of $\alpha\left(\alpha_{2}-\alpha_{7}\right)$ and $\beta\left(\beta_{2}-\beta_{4}\right)$ subunits. ${ }^{1}$ Compared with muscle $\mathrm{nAChR}$, little is known about functional aspects of neuronal $n A C h R$ in the brain. Peripherally, nAChR mediate the transmission of nerve impulses at sympathetic and parasympathetic ganglia and the release of catecholamines from adrenal medullary chromaffin cells. $^{2}$ Nicotinic receptors in bovine chromaffin cells are made up of $\alpha_{3}$ and $\alpha_{7}$ subunits and, therefore, belong to the neuronal subtypes of $n A C h R .^{3}$

Central nervous system nAChR have been implicated in the physiological regulation of human cognition, ${ }^{4}$ blood pressure, and heart rate, ${ }^{5}$ as well as in neuropsychiatric diseases including schizophrenia, ${ }^{6}$ movement disorders, ${ }^{7.8}$ Parkinson's disease, ${ }^{9,10}$ and analgesia." Despite their growing importance, there are few ligands and drugs to distinguish between the multiple neuronal nAChR subtypes. ${ }^{5}$ These new drugs will help to clarify their physiological role, and may eventually lead to novel therapeutic strategies to treat those neuropsychiatric disorders. In designing the novel, highly potent, neuronal nAChR blockers reported here, two principal pieces of evidence were initially considered. One relates to the guanidinium moiety of guanethidine and the other to the polyamines.
In a recent study, we tried to separate pharmacologically various $\mathrm{Ca}^{2+}$ entry pathways in bovine chromaffin cells stimulated with the selective agonist of $\mathrm{nAChR}$ 1,1-dimethyl-4-phenylpiperazinium iodide (DMPP), or with high $\mathrm{K}^{+}$depolarizing solutions. We found that guanethidine, a potent blocker of noradrenaline release from sympathetic nerve terminals ${ }^{12}$ and from chromaffin cells ${ }^{13}$ separated the $\mathrm{K}^{+}$and the DMPP responses. Thus, guanethidine fully blocked the ${ }^{45} \mathrm{Ca}^{2+}$ uptake induced by DMPP, but left intact the $\mathrm{K}^{+}$-evoked response. ${ }^{14}$ In this study the hypothesis was raised that guanethidine could be a blocker of some of the subtypes of the high-threshold $\mathrm{Ca}^{2+}$ channels described in bovine chromaffin cells. ${ }^{15}$ However, the fact that the drug did not block the $\mathrm{K}^{+}$-evoked $\mathrm{Ca}^{2+}$ uptake prompted us to consider the early suggestion of Jaanus et al. ${ }^{13}$ that a direct blockade of nAChR could explain the inhibition by guanethidine of ${ }^{45} \mathrm{Ca}^{2+}$ uptake into cells challenged with DMPP. This was the rationale for taking the guanidinium moiety present in the molecule of guanethidine as a model to design novel blockers for neuronal nAChR.

The second piece of evidence considered comes from the observation that sFTX blocks a subcomponent of the whole-cell $\mathrm{Ba}^{2+}$ current through $\mathrm{Ca}^{2+}$ channels in bovine chromaffin cells. ${ }^{15}$ sFTX is a synthetic analogue of a polyamine toxin present in the venom of the funnel-web spider Agelenopsis aperta, which blocks P-type voltage-dependent $\mathrm{Ca}^{2+}$ channels in neurones. ${ }^{16.17}$ These aliphatic polyamines include spermine, spermidine, putrescine, argiotoxin-636, and philantotoxins. They are known to inhibit various ionic channel subtypes, including the glutamatergic and the nAChR ion channels. ${ }^{18}$ 

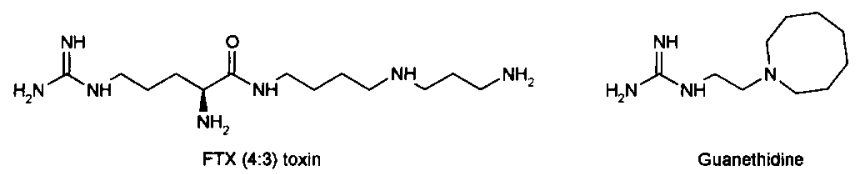

Figure 1. Molecular structure of the polyamine toxin fraction FTX from the funnel-web spider venom, and of guanethidine.

The presence of terminal amino or guanidinium groups, and the increase in the length of the polyamine chain enhance the inhibitory polyamine effects on glutamate responses. ${ }^{19,20}$ In this study we attempted to test the hypothesis that the introduction of two terminal guanidinium groups and amino groups, as well as the increasing length of the polyamine chain, could affect the $\mathrm{Ca}^{2+}$ entry pathways in depolarized bovine adrenal chromaffin cells. Although some of the synthetized molecules partially inhibited $\mathrm{Ca}^{2+}$ entry through $\mathrm{Ca}^{2+}$ channels, other molecules exhibited a particularly high efficacy in blocking $\mathrm{Ca}^{2+}$ entry induced by nAChR activation. Thus, we came across with a highly potent, novel class of nAChR blockers whose synthesis and pharmacological properties are reported here.

\section{Chemistry}

Several alkanediguanidinium salts were obtained exploring analogues of spider toxins FTX $^{21}$ (Fig. 1). The preparation (Fig. 2) was performed by reaction of the corresponding diamines 1 with $S$-methylisothiourea sulfate 2, yielding the guanidinium salt $\mathbf{3}$ with loss of mercaptan. ${ }^{22}$ Related compounds have been described as fungicides ${ }^{23-25}$ being $\mathbf{3 c}^{26}$ described in a patent. Similarly, related structures have been described as microbicides ${ }^{27}$, being $\mathbf{3 f}^{28}$ and $\mathbf{3 i}^{29}$ patented with that use. In the course of a research project on sympathetic nervous system blocking agents related to guanethidine, 3g was also described. ${ }^{30}$ Some other related compounds had been described as anion complexing agents. ${ }^{31}$


Figure 2. Synthesis of alkanediguanidinium salts.

\section{Results and Discussion}

Effects of alkanediguanidinium compounds on ${ }^{45} \mathrm{Ca}^{2+}$ uptake into chromaffin cells stimulated with high $\mathrm{K}^{+}$ or DMPP

The entry of ${ }^{45} \mathrm{Ca}^{2+}$ through $\mathrm{Ca}^{2+}$ channels was stimulated by direct depolarization of bovine chromaffin cells with high $\mathrm{K}^{+}$, or by indirect depolarization with the $n A C h R$ agonist DMPP. Concentrations of $\mathrm{K}^{+}(70$ $\mathrm{mM})$ and DMPP $(100 \mu \mathrm{M})$ producing similar increments of ${ }^{45} \mathrm{Ca}^{2+}$ entry were selected. ${ }^{14}$

Table 1 summarizes the results obtained with the 10 compounds studied at the concentration of $10 \mu \mathrm{M}$. Overall, the compounds were much more efficacious in blocking DMPP- than $\mathrm{K}^{+}$-induced ${ }^{45} \mathrm{Ca}^{2+}$ entry. Compounds $\mathbf{a}, \mathbf{f}, \mathbf{g}$, and $\mathbf{j}$ did not affect the $\mathrm{K}^{+}$signal. Compounds $\mathbf{b}$, e, and $\mathbf{i}$ inhibited the $\mathrm{K}^{+}$effects by $10 \%$ or less. Compound $\mathrm{c}$ blocked ${ }^{45} \mathrm{Ca}^{2+}$ uptake by $15 \%$ and compounds $\mathbf{d}$ and $\mathbf{h}$ by about $30 \% .{ }^{45} \mathrm{Ca}^{2+}$ uptake evoked by DMPP was unaffected by compound $\mathrm{g}$. Compounds a $(12 \%)$, and $\mathbf{h}(21 \%)$ caused a small blockade. Compounds $\mathbf{b}, \mathbf{i}$, and $\mathbf{j}$ approximately halved the DMPP signal. Finally, compounds $\mathbf{c}, \mathbf{d}$, e, and $\mathbf{f}$ inhibited by over $90 \%{ }^{45} \mathrm{Ca}^{2+}$ uptake.

The blocking effects of the DMPP response seemed to correlate well with the length of the aliphatic chain separating the two terminal guanidinium moieties. Thus, compound a (four $-\mathrm{CH}_{2}-$ groups) inhibited by $12 \%$ the DMPP signal, compound b (seven $-\mathrm{CH}_{2}-$ groups) by $53 \%$, and compounds c (eight $-\mathrm{CH}_{2}-$ groups), d (nine - $\mathrm{CH}_{2}-$ groups), e (10- $\mathrm{CH}_{2}-$ groups), and $\mathbf{f}\left(12-\mathrm{CH}_{2}-\right.$ groups) inhibited ${ }^{45} \mathrm{Ca}^{2+}$ uptake by $98,100,90$, and $91 \%$ respectively. A similar picture seemed to be true for compounds $g$ (no blockade), h ( $21 \%$ blockade), $\mathbf{i}$ ( $47 \%$ blockade) and $\mathbf{j}$ ( $61 \%$ blockade). It seems that a minimum length of the molecule is required to occupy its binding site on the $\mathrm{nAChR}$ and to inhibit the effect of DMPP. From these experiments, it is not possible, however, to define the

Table 1. Effects of alkanediguanidinium compounds on ${ }^{45} \mathrm{Ca}^{2+}$ uptake into chromaffin cells stimulated with high $\mathrm{K}^{+}$or DMPP (see Biological methods for details)

\begin{tabular}{lrcc}
\hline & & \multicolumn{2}{c}{$\%$ Inhibition } \\
\cline { 3 - 4 } Compound & $n$ & $70 \mathrm{mM} \mathrm{K}^{+}$ & $100 \mu \mathrm{M} \mathrm{DMPP}$ \\
\hline a & 9 & 0 & $12 \pm 5$ \\
b & 12 & $7.8 \pm 11$ & $52.8 \pm 7$ \\
c & 9 & $15.4 \pm 2.5$ & $98.3 \pm 0.5$ \\
d & 6 & $31.8 \pm 2.5$ & 100 \\
e & 9 & $10.5 \pm 5.2$ & $90.2 \pm 3.1$ \\
f & 9 & 0 & $90.7 \pm 4$ \\
g & 9 & 0 & 0 \\
h & 12 & $31.5 \pm 4.6$ & $20.9 \pm 4.7$ \\
i & 12 & $3.8 \pm 8.4$ & $46.7 \pm 8.6$ \\
j & 12 & 0 & $61.1 \pm 6.2$ \\
\hline
\end{tabular}

Data represent the percentage of inhibition of ${ }^{45} \mathrm{Ca}^{2+}$ uptake by 10 $\mu \mathrm{M}$ of each compound. They are means \pm SEM of the number of culture wells shown in $n$. DMPP, 1,1-dimethyl-4-phenylpiperazinium iodide. 
competitive or allosteric nature of the interaction on the nAChR between these compounds and DMPP.

To define further the nature of the effects of these compounds on the nAChR, additional studies on ${ }^{45} \mathrm{Ca}^{2+}$ uptake and ionic currents were performed. For this purpose, compound $\mathrm{e}$ which affected little the $\mathrm{K}^{+}$-evoked ${ }^{45} \mathrm{Ca}^{2+}$ uptake and inhibited by over $90 \%$ the DMPP signal, was selected.

Concentration-dependent effects of compound $e$ on ${ }^{45} \mathrm{Ca}^{2+}$ uptake induced by DMPP

Figure 3(A) shows the ${ }^{45} \mathrm{Ca}^{2+}$ taken up by unstimulated cells (basal) and by chromaffin cells stimulated with DMPP $(100 \mu \mathrm{M}$ for $60 \mathrm{~s})$ or high $\mathrm{K}^{+}(70 \mathrm{mM}$ for $60 \mathrm{~s})$, in the absence and presence of $10 \mu \mathrm{M}$ of compound $\mathbf{e}$. Compound $e$ did not affect the basal ${ }^{45} \mathrm{Ca}^{2+}$ taken up
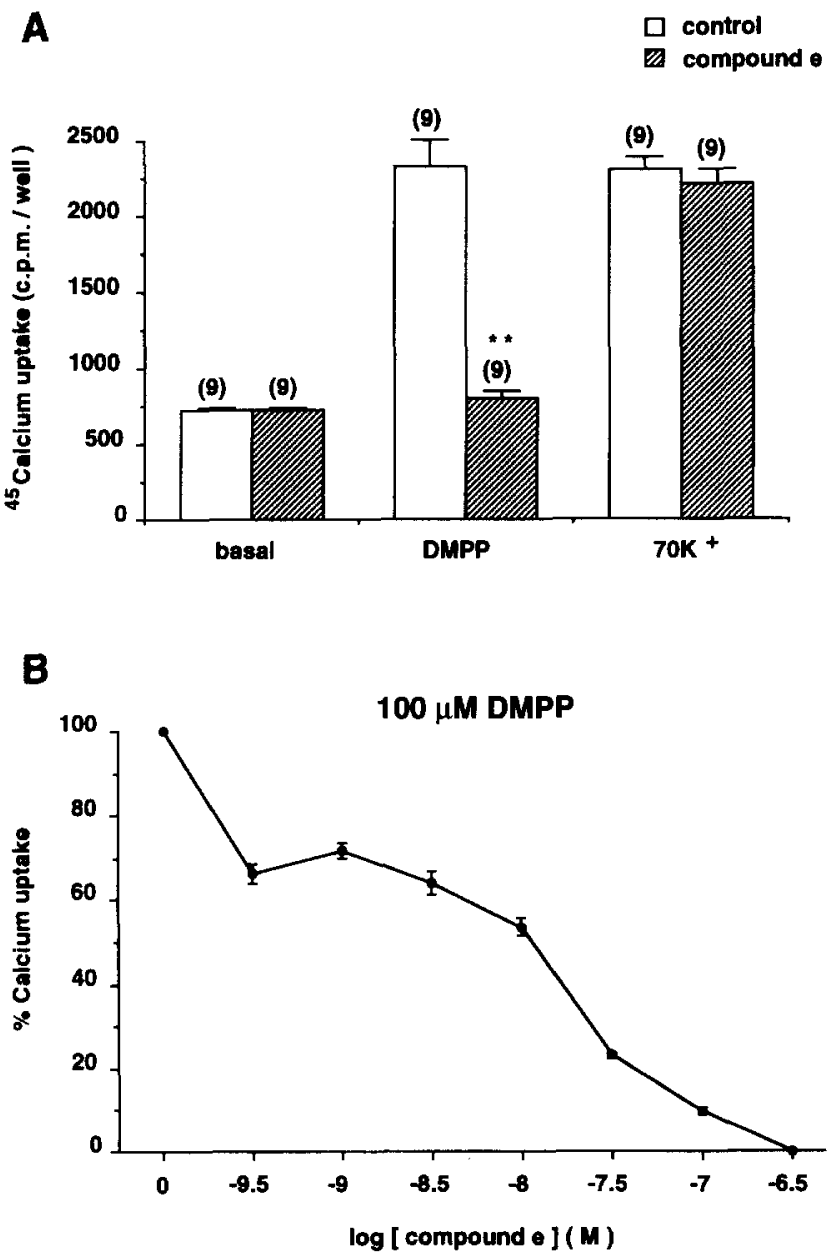

Figure 3. (A) ${ }^{45} \mathrm{Ca}^{2+}$ uptake into cultured bovine chromaffin cells. ${ }^{45} \mathrm{Ca}^{2+}$ taken up by cells in basal conditions was determined after incubation of the cells for $1 \mathrm{~min}$ in a normal Krebs-HEPES solution containing radiotracer $\mathrm{Ca}^{2+}$ (see Biological methods). Evoked $\mathrm{Ca}^{2+}$ uptake was studied by exposing the cells for $60 \mathrm{~s}$ to $100 \mu \mathrm{M}$ DMPP or $70 \mathrm{mM} \mathrm{K}$. Dashed columns show ${ }^{45} \mathrm{Ca}^{2+}$ uptake in the presence of $10 \mu \mathrm{M}$ of compound e, added $10 \mathrm{~min}$ before. Data are means + SEM of nine wells from three different cell cultures. (B) Concentration-response curve for compound $\mathbf{e}$, to block ${ }^{45} \mathrm{Ca}^{2+}$ uptake into chromaffin cells stimulated with DMPP. Experimental design as above. Data are means \pm SEM of 4-5 triplicate experiments from different cell batches. by cells. The increase in ${ }^{45} \mathrm{Ca}^{2+}$ uptake induced by DMPP was fully blocked by $10 \mu \mathrm{M}$ of compound $\mathbf{e}$, but the $\mathrm{K}^{+}$-evoked increase in ${ }^{45} \mathrm{Ca}^{2+}$ entry was unaffected.

Figure 3(B) shows a full concentration-response curve on the effects of compound e on DMPP-induced ${ }^{45} \mathrm{Ca}^{2+}$ uptake. Compound e inhibited the DMPP signal along a wide range of concentrations (more than $3 \mathrm{log}$ units). Its calculated $\mathrm{IC}_{50}$ was $20 \mathrm{nM}$, suggesting that the compound exhibits a high potency to block the nAChR-mediated signals.

\section{Effects of compound $e$ on ion currents through the nAChR}

Since these derivatives appeared to be rather active in blocking ${ }^{45} \mathrm{Ca}^{2+}$ uptake induced by DMPP, and because high $\mathrm{K}^{+}$and DMPP are both capable of opening $\mathrm{Ca}^{2+}$ channels in chromaffin cells, it seemed that these compounds would have a direct effect on the nicotinic receptor. We tested this possibility by using the more direct approach of measuring DMPP currents with the patch-clamp technique under the whole-cell configuration.

Figure 4 shows the time course of the current elicited by $250 \mathrm{~ms}$ pulses of $100 \mu \mathrm{M}$ DMPP, applied at $30 \mathrm{~s}$ intervals to a voltage-clamped chromaffin cell. The application of the compound immediately reduced the nAChR current to figures below $5 \%$. The blockade was maintained along five subsequent DMPP pulses, but was quickly reversed upon removal of compound $\mathbf{e}$ from the cell superfusion system. The reintroduction of the compound 7 min later produced a similar blockade that was fully reversed upon its washout.

\section{Ion channel selectivity of compound e}

To test whether compound e selectively blocked the nAChR current, the following experiment was carried out. A cell was voltage-clamped at $-80 \mathrm{mV}$ and at $30 \mathrm{~s}$ intervals a pair of separate stimuli were applied. The first stimulus consisted of the application of $100 \mu \mathrm{M}$ DMPP for $250 \mathrm{~ms}$ (inward current through the $\mathrm{nAChR}$ ); then, $2 \mathrm{~s}$ later, a depolarizing test pulse to 0 $\mathrm{mV}$ and $50 \mathrm{~ms}$ duration was given (inward currents through voltage-dependent $\mathrm{Na}^{+}$and $\mathrm{Ca}^{2+}$ channels). These paired stimuli were repeatedly given before, during and after the application of compound $\mathbf{e}(10$ $\mu \mathrm{M}$ ) [see protocol on top of Figure 5(A)]. The initial $I_{\text {DMPP }}$ peak elicited (ca. $2400 \mathrm{pA}$ ) was reduced to around $100 \mathrm{pA}$ in the presence of the compound. In contrast, neither $I_{\mathrm{Na}}$ (first peak of the current traces shown in the right part of panel A) nor $I_{\mathrm{Ca}}$ [plateau of the current traces in right part of Fig. 5(A)] were affected by compound $e$. In the presence of the compound, the residual $I_{\mathrm{DMPP}}$ current left unblocked was around $10 \%$, while over $90 \%$ of $I_{\mathrm{Ca}}$ remained intact [Fig. 5(B)].

In conclusion, the alkanediguanidinium compounds synthetized act as blockers of ion fluxes through the neuronal nAChR. This blockade is exerted at 
nanomolar concentrations, suggesting a highly selective interaction with $\mathrm{nAChR}$. In fact, the voltage-dependent $\mathrm{Na}^{+}$and $\mathrm{Ca}^{2+}$ channels are not recognized by these compounds. The alkanediguanidinium compounds might recognize selective subtypes of neuronal nAChR, although it remains to be elucidated if skeletal muscle $\mathrm{nAChR}$ are also targetted by these compounds. These compounds may become useful tools to clarify the functions of such receptors in the central and peripheral nervous systems. Eventually, further structural modulation of these molecules might lead to compounds useful in the treatment of neuropsychiatric diseases in which nAChR have been implicated.

\section{Chemistry}

\section{Experimental}

Melting points were determined on a Büchi SMP-20 and are uncorrected. IR spectra $(\mathrm{KBr})$ were recorded using a Perkin-Elmer 599B spectrophotometer. 'H NMR spectra were obtained on a Varian Unity 300 $(300 \mathrm{MHz})$ spectrometer. Chemical shifts are expressed in ppm downfield from tetramethylsilane. Elemental analyses were carried out on a Heraeus rapid $\mathrm{CHN}$ analyser. All chemicals were commercially purchased and purified before using when necessary. CAUTION: ethylmercaptan is evolved.

\section{Preparation of alkanediguanidinium salts}

General procedure. A mixture of the corresponding diamine $(3 \mathrm{mmol})$ and $S$-methylisothiourea sulfate $(2.5$ $\mathrm{g}, 9 \mathrm{mmol})$ were dissolved in water $(2 \mathrm{~mL})$. The mixture was heated to reflux for the time indicated in each case. Then, the mixture was allowed to stand at room temperature for $24 \mathrm{~h}$, and a white precipitate appeared. The solid was filtered, washed with water $(2 \times 1 \mathrm{~mL})$ and acetone $(2 \times 1 \mathrm{~mL})$ being crystallized from water.

Butane-1,4-diguanidinium sulfate (3a). According to the general procedure, starting from butane1,4-diamine $(0.264 \mathrm{~g})$, the mixture was heated for $5 \mathrm{~h}$, and after the usual work up, $3 \mathbf{a}$ was isolated as white prisms (500 mg, 62\%), mp $299-303{ }^{\circ} \mathrm{C}(\mathrm{dec})$. IR ( $\mathrm{v}$, $\mathrm{cm}^{-1}$ ): $3343,3132,2940,1679,1626,1481,1452,1383$, 1074, 749. ' $\mathrm{H}$ NMR ( $\left.\mathrm{CF}_{3} \mathrm{COOD}\right): 3.40(\mathrm{~m}, 4 \mathrm{H}) ; 1.84$ (m, $4 \mathrm{H})$. Anal. calcd for $\mathrm{C}_{6} \mathrm{H}_{18} \mathrm{~N}_{6} \mathrm{O}_{4} \mathrm{~S} \cdot 1 / 2 \mathrm{H}_{2} \mathrm{O}: \mathrm{C}, 25.79$; H, 6.36; N, 30.09. Found: C, 26.12; H, 6.55; N, 29.61 .
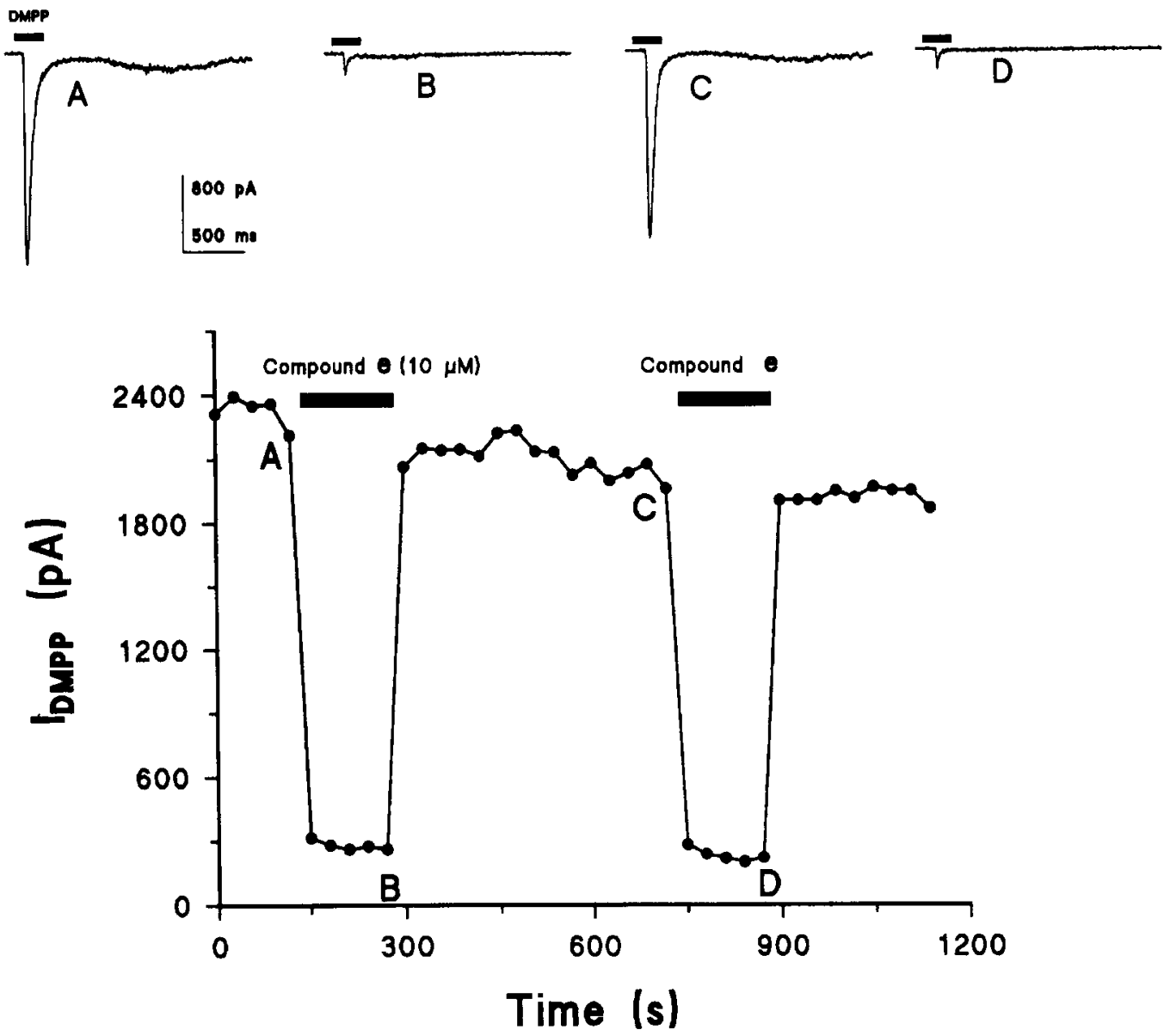

Figure 4. Time course for the blocking effects and washout of $10 \mu \mathrm{M}$ of compound e on the peak current induced by $250 \mathrm{~ms}$ pulses of DMPP $\left(I_{\text {DMPP }}\right)$ in a voltage-clamped bovine chromaffin cell. The holding potential of the cell was maintained at $-80 \mathrm{mV}$. DMPP pulses were applied at $30 \mathrm{~s}$ intervals. Insets on top of the figure labeled with letters $\mathrm{A}, \mathrm{B}, \mathrm{C}$, and $\mathrm{D}$ show original traces obtained at the points indicated on the time course curve. 
Heptane-1,7-diguanidinium sulfate (3b). According to the general procedure, starting from heptane1,7-diamine $(0.39 \mathrm{~g})$, the mixture was heated for $7 \mathrm{~h}$, and after the usual work up, 3b was isolated as white prisms (460 mg, $49 \%$ ), mp $314-318^{\circ} \mathrm{C}$ (dec). IR ( $v$ $\left.\mathrm{cm}^{-1}\right): 3374,3159,2938,1662,1086,726 .{ }^{1} \mathrm{H}$ NMR $\left(\mathrm{CF}_{3} \mathrm{COOD}\right): 2.77(\mathrm{t}, 4 \mathrm{H}, J=7.1 \mathrm{~Hz}) ; 1.19$ (bs, 4H); 0.93 (bs, $6 \mathrm{H}$ ). Anal. calcd for $\mathrm{C}_{9} \mathrm{H}_{24} \mathrm{~N}_{6} \mathrm{O}_{4} \mathrm{~S}: \mathrm{C}, 34.60 ; \mathrm{H}$, $7.74 ; \mathrm{N}, 26.90$; S, 10.26. Found: C, 34.40; H, 7.97; N, $27.10 ;$ S. 10.50 .

Octane-1,8-diguanidinium sulfate $(3 \mathrm{c})$. According to the general procedure, starting from octane1,8-diamine $(0.432 \mathrm{~g})$, the mixture was heated for $5 \mathrm{~h}$, and after the usual work up, $3 \mathbf{c}$ was isolated as white prisms $(583 \mathrm{mg}, 60 \%), \mathrm{mp} 314-317^{\circ} \mathrm{C}$. IR $\left(\nu, \mathrm{cm}^{-1}\right)$ :
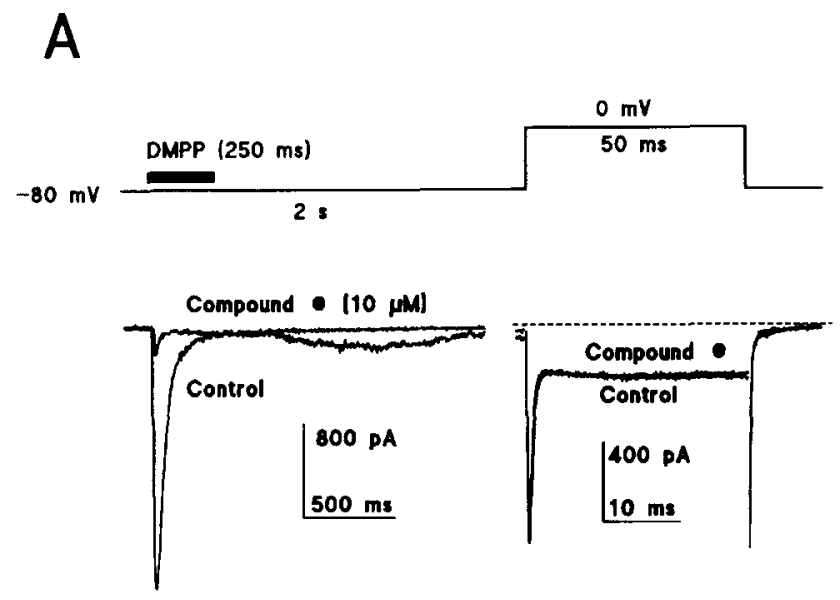

B

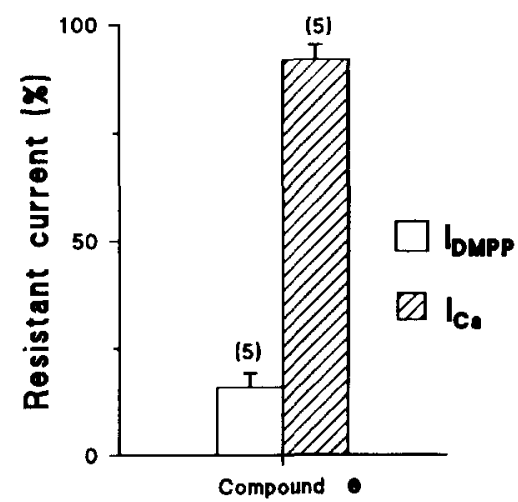

Figure 5. The protocol used to simultaneously record $I_{\mathrm{DMPP}}, I_{\mathrm{Ca}}$ and $I_{\mathrm{Ni}}$ in voltage-clamped chromaffin cells is shown on the top part of the figure. Part (A) shows the current recorded after brief $(250 \mathrm{~ms})$ applications of a solution containing $100 \mu \mathrm{M}$ DMPP ( $I_{\mathrm{DMPP}}$ ), applied at $30 \mathrm{~s}$ intervals to cells held at a membrane potential of $-80 \mathrm{mV}$ in an individual cell. They represent the control $I_{\mathrm{DMPP}}$ and that in the presence of $10 \mu \mathrm{M}$ of compound $e$. The right panel shows the effects of compound $\mathrm{e}$ on $I_{\mathrm{Na}}$ and $I_{\mathrm{Ca}}$ evoked by $50 \mathrm{~ms}$ depolarizing pulses to $0 \mathrm{mV}$ applied from a holding potential of $-80 \mathrm{mV}$. Part (B) shows averaged data on the blockade of $10 \mu \mathrm{M}$ compound e on $I_{\mathrm{DMPP}} I_{\mathrm{N}}$ and $I_{\mathrm{Ca}}$ in bovine chromaffin cells. Data correspond to the mean \pm SEM of the number of cells shown in parentheses on top of each bar.
$3359,3168,2934,1644,1475,1382,1107 .{ }^{1} \mathrm{H}$ NMR $\left(\mathrm{CF}_{3} \mathrm{COOD}\right): 3.36(\mathrm{t}, 4 \mathrm{H}) ; 1.74(\mathrm{~m}, 4 \mathrm{H}) ; 1.47(\mathrm{bs}, 8 \mathrm{H})$. Anal. calcd for $\mathrm{C}_{10} \mathrm{H}_{26} \mathrm{~N}_{6} \mathrm{O}_{4} \mathrm{~S} \cdot 1 / 2 \mathrm{H}_{2} \mathrm{O}: \mathrm{C}, 35.81 ; \mathrm{H}, 8.11$; N, 25.05. Found: C, 36.18; H, 8.07; N, 24.77.

Nonane-1,9-diguanidinium sulfate (3d). According to the general procedure, starting from nonane1,9-diamine $(0.474 \mathrm{~g})$, the mixture was heated for $5 \mathrm{~h}$, and after the usual work up, $3 \mathbf{d}$ was isolated as white prisms $(560 \mathrm{mg}, 55 \%), \mathrm{mp} 302-306{ }^{\circ} \mathrm{C}$ (dec). IR (v, $\left.\mathrm{cm}^{-1}\right): 3364,3168,2934,1644,1118,1056 .{ }^{\prime} \mathrm{H}$ NMR ( $\left.\mathrm{CF}_{3} \mathrm{COOD}\right): 2.75$ (bs, 4H); 1.19 (bs, 4H); 0.88 (bs, $10 \mathrm{H})$. Anal. calcd for $\mathrm{C}_{11} \mathrm{H}_{28} \mathrm{~N}_{6} \mathrm{O}_{4}: \mathrm{C}, 37.80 ; \mathrm{H}, 8.36 ; \mathrm{N}$, 24.05. Found: $\mathrm{C}, 37.75 ; \mathrm{H}, 8.59 ; \mathrm{N}, 24.31$.

Decane-1,10-diguanidinium sulfate (3e). A solution of $S$-methylisothiourea sulfate $(0.550 \mathrm{~g}, 2 \mathrm{mmol})$ in water $(2 \mathrm{~mL})$ was added to a solution of decane1,10-diamine $(0.344 \mathrm{~g}, 2 \mathrm{mmol})$ in acetonitrile $(1 \mathrm{~mL})$. The mixture was heated to reflux for $18 \mathrm{~h}$, and a precipitate appeared. Water $(3 \mathrm{~mL})$ was added, and the mixture was allowed to cool. The solid was filtered and washed with acetone $(2 \mathrm{~mL})$ and diethyl ether $(10 \mathrm{~mL})$ to give 3e (509 mg, 72\%), mp 262-266 ${ }^{\circ} \mathrm{C}$. IR ( $\mathrm{v}$, $\mathrm{cm}^{-1}$ ): 3361, 3146, 2930, 2856, 1640, 1112, 1078. ${ }^{1} \mathrm{H}$ NMR $\left(\mathrm{CF}_{3} \mathrm{COOD}\right): 2.80(\mathrm{t}, 4 \mathrm{H}) ; 1.20(\mathrm{bt}, 4 \mathrm{H}) ; 0.90$ (bs, $12 \mathrm{H}$ ). Anal. calcd for $\mathrm{C}_{12} \mathrm{H}_{31} \mathrm{~N}_{6} \mathrm{O}_{4} \mathrm{~S}: \mathrm{C}, 40.66 ; \mathrm{H}$, $8.53 ; \mathrm{N}, 23.71 ; \mathrm{S}, 9.04$. Found: $\mathrm{C}, 40.79 ; \mathrm{H}, 8.80 ; \mathrm{N}$, $23.81 ; \mathrm{S}, 9.32$.

Dodecane-1,12-diguanidinium sulfate (3f). According to the general procedure, starting from dodecane1,12-diamine $(0.6 \mathrm{~g})$, the mixture was heated for $10 \mathrm{~h}$, and after the usual work up $3 \mathbf{3 f}$ was isolated as white prisms $(600 \mathrm{mg}, 52 \%), \mathrm{mp} 258-262^{\circ} \mathrm{C}$. IR $\left(\mathrm{v}, \mathrm{cm}^{-1}\right)$ : $3165,2923,2854,1685,1631,1116,1079$. ' $\mathrm{H}$ NMR $\left(\mathrm{CF}_{3} \mathrm{COOD}\right): 2.74(\mathrm{t}, 4 \mathrm{H}) ; 1.18(\mathrm{~m}, 4 \mathrm{H}) ; 0.84(\mathrm{~m}$, $16 \mathrm{H}$ ). Anal. calcd for $\mathrm{C}_{14} \mathrm{H}_{34} \mathrm{~N}_{6} \mathrm{O}_{4} \mathrm{~S}$ : C, 43.96; H, 8.59; N, 21.97; S. 8.38. Found: C, 44.18; H, 8.87; N, 21.78; S, 8.12 .

\section{Preparation of azaalkanediguanidinium salts}

General procedure. A mixture of the corresponding polyamine $(9 \mathrm{mmol})$ and $S$-methylisothiourea sulfate $(2.78 \mathrm{~g}, 10 \mathrm{mmol})$ in dry acetonitrile $(25 \mathrm{~mL})$ was heated to reflux under argon for the time indicated. After cooling to room temperature, the precipitate was filtered, washed with acetonitrile $(10 \mathrm{~mL})$, and crystallized from water.

3-Azapentane-1,5-diguanidinium sulfate (3g). According to the general procedure, starting from $N$-(2-aminoethyl)ethane-1,2-diamine $(0.927 \mathrm{~g}), \quad$ the mixture was heated for $17 \mathrm{~h}$, and after the usual work up, $\mathbf{3 g}$ was isolated as white prisms $(2.37 \mathrm{~g}, 87 \%)$, mp $307-310^{\circ} \mathrm{C}$. IR $\left(\mathrm{v}, \mathrm{cm}^{-1}\right): 3167,2826,1648,1460,1346$, 1291, 1264, 1109, 895, 618. ${ }^{1} \mathrm{H}$ NMR $\left(\mathrm{D}_{2} \mathrm{O}\right) 3.08(\mathrm{t}$, $4 \mathrm{H}) ; 2.57$ (t, $4 \mathrm{H})$. Anal. calcd for $\mathrm{C}_{6} \mathrm{H}_{19} \mathrm{~N}_{7} \mathrm{O}_{4} \mathrm{~S} \cdot \mathrm{H}_{2} \mathrm{O}$ : C, $23.75 ; \mathrm{H}, 6.98 ; \mathrm{N}, 32.32 ; \mathrm{S}, 10.57$. Found: $\mathrm{C}, 23.75 ; \mathrm{H}$, $7.50 ; \mathrm{N}, 32.98 ; \mathrm{S}, 10.41$. 
3-Azahexane-1,6-diguanidinium sulfate (3h). According to the general procedure, starting from $\mathrm{N}$-(2aminoethyl)propane-1,3-diamine (1.05 g), the mixture was heated for $19 \mathrm{~h}$, and after the usual work up, $\mathbf{3 h}$ was isolated as white prisms $(2.62 \mathrm{~g}, 78 \%), \mathrm{mp} 192{ }^{\circ} \mathrm{C}$ (dec). IR ( $\left.\mathrm{v}, \mathrm{cm}^{-1}\right): 3383,2528,2358,2324,2083,1645$, $1525,1480,1367,1255,1124,862,762,664,617 .{ }^{1} \mathrm{H}$ NMR ( $\left.\mathrm{D}_{2} \mathrm{O}\right) 3.53(\mathrm{t}, 2 \mathrm{H}) ; 3.17(\mathrm{~m}, 4 \mathrm{H}) ; 2.18(\mathrm{t}, 2 \mathrm{H})$; $1.94(\mathrm{~m}, 2 \mathrm{H})$. Anal. calcd for $\mathrm{C}_{7} \mathrm{H}_{21} \mathrm{~N}_{7} \mathrm{O}_{7.5} \mathrm{~S}_{1.5}: \mathrm{C}, 22.45$; $\mathrm{H}, 6.46 ; \mathrm{N}, 26.18 ; \mathrm{S}, 12.84$. Found: C, 22.71; H, 7.27; N, $26.03 ; \mathrm{S}, 13.13$.

4-Azaheptane-1,7-diguanidinium sulfate (3i). According to the general procedure, starting from 3,3'-diaminopropylamine $(1.18 \mathrm{~g})$, the mixture was heated for 22 $\mathrm{h}$, and after the usual work up, $3 \mathbf{i}$ was crystallized from EtOH: $\mathrm{H}_{2} \mathrm{O}(1: 5,2.32 \mathrm{~g}, 65 \%), \mathrm{mp} 280-283^{\circ} \mathrm{C}$. IR ( $\mathrm{v}$, $\left.\mathrm{cm}^{-1}\right): 3356,3183,2959,2806,1648,1457,1124,618$. ${ }^{1} \mathrm{H}$ NMR $\left(\mathrm{D}_{2} \mathrm{O}\right) 3.08(\mathrm{t}, 4 \mathrm{H}) ; 2.90(\mathrm{t}, 4 \mathrm{H}) ; 1.77(\mathrm{~m}$, $4 \mathrm{H}$ ). Anal. calcd for $\mathrm{C}_{8} \mathrm{H}_{28} \mathrm{~N}_{7} \mathrm{O}_{8} \mathrm{~S}_{1.5}: \mathrm{C}, 24.11 ; \mathrm{H}, 7.08$; N, 24.60; S, 12.07. Found: C, 24.96; H, 7.10; N, 24.25; $\mathrm{S}, 11.43$.

4,7-Diazadecane-1,10-diguanidinium sulfate $(3 \mathrm{j})$. According to the general procedure, starting from $N, N^{\prime}$-bis(3-aminopropyl)ethane-1,2-diamine $(1.57 \mathrm{~g})$, the mixture was heated for $17 \mathrm{~h}$, and after the usual work up, 3j was crystallized from EtOH: $\mathrm{H}_{2} \mathrm{O}(1: 5$, $2.72 \mathrm{~g}, 62 \%), \mathrm{mp} 288-290^{\circ} \mathrm{C}$. IR $\left(\mathrm{v}, \mathrm{cm}^{-1}\right): 3132,2732$, $2468,1691,1641,1521,1480,1403,1383,1068,968$, 795, 746, 626. ${ }^{1} \mathrm{H}$ NMR $\left(\mathrm{CF}_{3} \mathrm{COOD}\right): 3.86(\mathrm{~m}, 4 \mathrm{H})$; $3.50(\mathrm{~m}, 8 \mathrm{H}) ; 2.36-2.26(\mathrm{~m}, 4 \mathrm{H})$. Anal. calcd for $\mathrm{C}_{10} \mathrm{H}_{30} \mathrm{~N}_{8} \mathrm{O}_{8} \mathrm{~S}_{2} \cdot 2 \mathrm{H}_{2} \mathrm{O}: \quad \mathrm{C}, 24.48 ; \mathrm{H}, 6.98 ; \mathrm{N}, 22.84$. Found: C, 25.14; H, 7.32; N, 22.28 .

\section{Biological methods}

Isolation and culture of bovine chromaffin cells. Bovine adrenal medullary chromaffin cells were isolated following standard methods ${ }^{32}$ with some modifications. ${ }^{33}$ Cells were suspended in Dulbecco's modified Eagle's medium (DMEM) supplemented with 5\% foetal calf serum, $10 \mu \mathrm{M}$ cytosine arabinoside, $10 \mu \mathrm{M}$ fluorodeoxyuridine, $50 \mathrm{IU} \mathrm{mL} \mathrm{mL}^{-1}$ penicillin and $50 \mu \mathrm{g}$ $\mathrm{mL}^{-1}$ streptomycin. Cells were plated at a density of $5 \times 10^{5}$ cells/well in 24-multiwell Costar plates for ${ }^{45} \mathrm{Ca}^{2+}$ uptake studies and were used 1-5 days after plating. For whole-cell current experiments, cells were plated on glass coverslips at a density of $25 \times 10^{3}$ cells $\mathrm{mL}^{-1}$. Medium was replaced after $24 \mathrm{~h}$ and then after 2-3 days.

Measurements of ${ }^{45} \mathrm{Ca}^{2+}$ uptake. ${ }^{45} \mathrm{Ca}^{2+}$ uptake studies were carried out in cells after 1-5 days in culture. Before the experiment, cells were washed twice with $0.5 \mathrm{~mL}$ Krebs-HEPES solution, of the following composition (mM): $\mathrm{NaCl} 140, \mathrm{KCl} 5.9, \mathrm{MgCl}_{2} 1.2$, $\mathrm{CaCl}_{2} 1$, glucose 11 , HEPES 10 , at $\mathrm{pH} 7.2$, at $37^{\circ} \mathrm{C}$.

${ }^{45} \mathrm{Ca}^{2+}$ uptake into chromaffin cells was studied by incubating the cells at $37{ }^{\circ} \mathrm{C}$ with ${ }^{45} \mathrm{CaCl}_{2}$ at a final concentration of $5 \mu \mathrm{Ci} \mathrm{mL}^{-1}$ in the presence of KrebsHEPES (basal uptake), high $\mathrm{K}^{+}$solution (Krebs-
HEPES containing $70 \mathrm{mM} \mathrm{KCl}$ with isosmotic reduction of $\mathrm{NaCl}$ ), or $100 \mu \mathrm{M}$ dimethylphenylpiperazinium (DMPP) in Krebs-HEPES. This incubation was carried out during $1 \mathrm{~min}$ and at the end of this period the test medium was rapidly aspirated and the evoked ${ }^{45} \mathrm{Ca}^{2+}$ uptake period was ended by adding 0.5 $\mathrm{mL}$ of a cold $\mathrm{Ca}^{2+}$-free Krebs-HEPES containing 10 $\mathrm{mM} \mathrm{LaCl}{ }_{3}$. Finally, cells were washed five times more with $0.5 \mathrm{~mL}$ of $\mathrm{Ca}^{2+}$-free Krebs-HEPES containing 10 $\mathrm{mM} \mathrm{LaCl}{ }_{3}$ and $2 \mathrm{mM} \mathrm{EGTA}$, at $15 \mathrm{~s}$ intervals.

To measure radioactivity retained, cells were scraped with a plastic pipette tip while adding $0.5 \mathrm{~mL} 10 \%$ trichloroacetic acid, $3.5 \mathrm{~mL}$ scintillation fluid (Ready Micro, Beckman) was added and the samples counted in a Packard beta counter. Results are expressed as cpm $5 \times 10^{5}$ cells $^{-1}$ or as $\%$ of $\mathrm{Ca}^{2+}$ taken up by control cells.

Electrophysiological recordings. DMPP-induced currents and $\mathrm{Ca}^{2+}$ currents through $\mathrm{Ca}^{2+}$ channels were recorded using the whole-cell configuration of the patch-clamp technique. ${ }^{34}$ Cells plated on glass coverslips were placed on an experimental chamber mounted on the stage of an inverted microscope. The chamber was continuously perfused with Tyrode solution containing (in $\mathrm{mM}$ ): $137 \mathrm{NaCl}, 1 \mathrm{MgCl}_{2}, 2$ $\mathrm{CaCl}_{2}, 10$ HEPES, titrated to $\mathrm{pH} 7.4$ with $\mathrm{NaOH}$. Recording electrodes (2-5 M 2 ) were filled with a solution containing (in $\mathrm{mM}$ ): $10 \mathrm{NaCl}, 100 \mathrm{CsCl}, 20$ TEA $\mathrm{Cl}, 5 \mathrm{Mg} \cdot \mathrm{ATP}, 14$ EGTA, $20 \mathrm{HEPES}, 0.3 \mathrm{GTP}$, titrated to $\mathrm{pH} 7.2$ with $\mathrm{CsOH}$. Experiments were carried out at room temperature $\left(23-25^{\circ} \mathrm{C}\right)$. Extracellular solutions were changed rapidly by using a multi-barreled pipette with a common outlet placed within $100 \mu \mathrm{m}$ from the cell under observation. Wholecell recordings were made with a DAGAN 8900 amplifier. Data acquisition and analysis were performed using pClamp software.

\section{Acknowledgments}

This work has been supported in part by grants from Lilly, S.A., Madrid, Spain, and Dirección General de Investigación Científica y Técnica (DGICYT no. PM92-0039 and no. PB94-0150), and Fundación Ramón Areces, to AGG. We thank Mrs M.C. Molinos the typing of this manuscript.

\section{References}

1. Sargent, P. B. Ann. Rev. Neurosci. 1993, 16, 403.

2. Douglas, W. W.; Rubin, R. P. J. Physiol. 1961, 159, 40.

3. García-Guzmán, M.; Sala, F.; Sala, S.; Campos-Caro, A.; Stühmer, W.; Gutiérrez, L. M.; Criado, M. Eur. J. Neurosci. 1995, 7, 647 .

4. Warburton, D. M. Prog. Neuro-Psychopharmacol. Biol. Psychiat. 1992, 16, 181.

5. Khan, I. M.; Taylor, O.; Yaksh, T. L. J. Pharmacol. Exp. Ther. 1994, 270, 150. 
6. Adler, L. E.; Hoffer, L. D.; Wiser, A.; Freedman, R. Am. J. Psychiat. 1993, 150, 1856

7. Lieberman, J. A.; Bradley, R. J.; Rubinstein, M.; Kane, J. M. Lancet 1984, $i, 1066$.

8. Sanberg, P. R.; McConville, B. J.; Fogelson, H. M.; Manderscheid, P. Z.; Parker, K. W.; Blythe, M. M.; Klykylo, W. M.; Norman A. B. Biomed. Pharmacother. 1989, 43, 19.

9. Janson, A. M.; Fuxe, K.; Sundstrom, E.; Agnati, L. F.; Golgstgein, M. Acta Physiol. Scand. 1988, 132, 589.

10. Decker, M. W.; Brioni, J. D.; Bannon, A. W.; Arneric, S. P. Life Sci. 1995, 56, 545 .

11. Badio, B.; Dali, J. W. Mol. Pharmacol. 1994, 45, 563.

12. Kirpekar, S. M. Prog. Neurobiol. 1975, 4, 63.

13. Jaanus, S. D.; Miele, E.; Rubin, R. P. Br. J. Pharmacol. Chemother. 1968, 33, 560.

14. Gandía, L.; Casado, L.-F.; López, M. G.; García, A. G. Br. J. Pharmacol. 1991, 103, 1073.

15. Gandía, L.; Albillos, A.; García, A. G. Biochem. Biophys. Res. Commun. 1993, 194, 671.

16. Llinás, R.; Sugimori, M.; Lin, J. W.; Chersksey, B. Proc. Natl. Acad. Sci. U.S.A. 1989, 86, 1689.

17. Usowicz, M. M.; Sugimori, M.; Cherksey, B.; Llinás, R. Neuron 1992, 9, 1185.

18. Scott, R. H.; Sutton, K. G.; Dolphin, A. C. Trends Neurosci. 1993, 16, 153.

19. Unserwood, P. N. R.; Blagbrough, I. S. Pharmacol. Ther. 1992, 52, 245.

20. Benson, J. A.; Schürmann, F.; Kaufmann, L.; Gsell, L.; Piek, T. Comp. Biochem. Physiol. 1992, 102C, 267
21. Cherksey, B. D.; Sugimori, M.; Llinás, R. Ann. N.Y. Acad. Sci. 1991, 635, 80.

22. Brand, E.; Brand, F. C. Org. Synth. Coll. 1953, 3, 440.

23. Worthing, C. R.; Walker, S. B. The pesticide manual, a world compendium, 8th ed.; Thornton Heath: British Crop Protection Council, 1987; p 451.

24. Evans Medical Ltd. Antifungal Biguanidine Derivatives, Fr. M. 5, 207, 1967.

25. Evans Medical Ltd. Guanidine Derivatives Neth. Appl. 6, $511,047,1966$.

26. Brown, J. G.; Payne, H. A. S. Fungicidal 1,8-diguanidinooctane Salts. Ger. Offen 2, 219, 461, 1972.

27. Takahasi, Y.; Fujimoto, E.; Simizzu, T.; Tsurumi, T. Guanidine Organic Salts Microbicides. Japan: Kokai, 1978; Vol. 41, p 426.

28. Dainippon Ink and Chemical, Inc. Polymethylene bisguanidino Compounds as Microbicides for Rice. Japan: Kokai, Tokyo Koho JP 82 48, 1982; p 902.

29. Ueda, T. Bis(guanidinopropyl)amine Derivatives. Japan, 1963; Vol. 24, p 177 (65).

30. Short, J. H.; Biermacher, U.; Dunnigan, D. A.; Leth, T. D. J. Med. Chem. 1963, 6, 275.

31. Dietrich, B.; Fyles, D. L.; Fyles, T. M.; Lehn, J. M. Helv. Chim. Acta 1979, 62, 2763.

32. Livett, B. G. Physiol. Rev. 1984, 64, 1103.

33. Moro, M. A.; López, M. G.; Gandía, L.; Michelena, P.; García, A. G. Anal. Biochem. 1990, 185, 243.

34. Hamill, O. P.; Marty, A.; Neher, E.; Sakmann, B.; Sigworth, F. J. Pflügers Arch. Eur. J. Physiol. 1981, 391, 85.

(Received in U.S.A. 1 November 1995, accepted 14 March 1996) 